\title{
New Regional Editor
}

\author{
Shyamala Bharadwaj
}

Received: 2 November 2010/Accepted: 3 November 2010/Published online: 16 December 2010

(c) Akadémiai Kiadó, Budapest, Hungary 2010

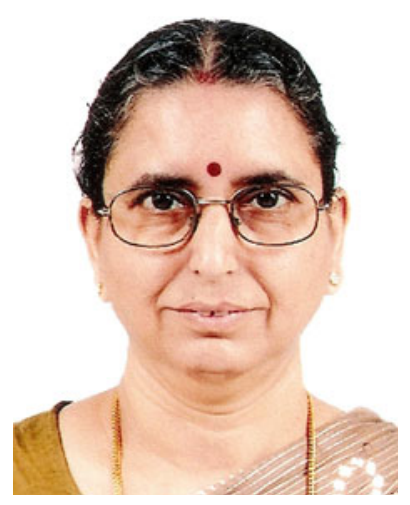

Dr. Shyamala Bharadwaj is presently Head, Fuel Cell Materials \& Catalysis Section, Chemistry Division, Bhabha Atomic Research Centre, Mumbai, India. She obtained her M.Sc. in Chemistry in 1981 and her Ph.D. in Physical Chemistry in 1991 from Mumbai University. Her main area of work during the past 30 years has been determination of thermodynamic properties of nuclear materials using various techniques such as vapour pressure measurements, thermogravimetry, isoperibol calorimeter, etc. During 2000-2001, she worked as guest scientist at Juelich Research Centre, Juelich, Germany on Solid Oxide Fuel Cell (SOFC) materials. Her current interests are in the fields of Intermediate Temperature Solid Oxide Fuel Cells (ITSOFC) and sulphur-iodine thermochemical cycle for generation of hydrogen from water. She was awarded the NETZSCH-ITAS Award (2006) by the Indian Thermal Analysis Society in the year 2006 for her contributions in the field of thermal analysis. She has more than 95 papers in refereed international journals and more than 100 papers in National and International Symposia. She served two terms (2003-2009) as Hon. General Secretary of Indian Thermal Analysis and during this period she was involved in organizing several national symposia and workshops on Thermal Analysis. She has been one of editors of Proceedings of National Symposium on Thermal Analysis held biennially at various places in India during the period 1991 to 2010 .

S. Bharadwaj $(\bowtie)$

Fuel Cell Materials \& Catalysis Section, Chemistry Division, Bhabha Atomic Research Centre, Mumbai 400 085, India

e-mail: shyamala@barc.gov.in 